\title{
Active Corrosion Protection of Mg-Al Layered Double Hydroxide for Magnesium Alloys: A Short Review
}

\author{
Xinfang Zhang ${ }^{1,2}$, Min Zhang ${ }^{3, *}$, Ruihong Li ${ }^{2, *}$, Xiaoyan Feng ${ }^{2}$, Xue Pang ${ }^{2}$, Jinsong Rao ${ }^{1}$, Dalong Cong ${ }^{3}$, \\ Changqing Yin ${ }^{1}$ and Yuxin Zhang ${ }^{1, *(D)}$ \\ 1 College of Materials Science and Engineering, Chongqing University, Chongqing 400044, China; \\ 202109021146t@cqu.edu.cn (X.Z.); rjs@cqu.edu.cn (J.R.); CorsacY@163.com (C.Y.) \\ 2 School of Materials and Metallurgy, Inner Mongolia University of Science and \\ Technology, Baotou 014010, China; fengxy411@163.com (X.F.); pangxue1520@163.com (X.P.) \\ 3 Southwest Institute of Technology and Engineering, Chongqing 400039, China; congd109@163.com \\ * Correspondence: zhmcq59@163.com (M.Z.); liruihong@imust.edu.cn (R.L.); zhangyuxin@cqu.edu.cn (Y.Z.)
}

Citation: Zhang, X.; Zhang, M.; Li, R.; Feng, X.; Pang, X.; Rao, J.; Cong, D.; Yin, C.; Zhang, Y. Active

Corrosion Protection of $\mathrm{Mg}-\mathrm{Al}$ Layered Double Hydroxide for Magnesium Alloys: A Short Review. Coatings 2021, 11, 1316. https:// doi.org/10.3390/coatings11111316

Academic Editor: Pier Luigi Bonora

Received: 25 September 2021

Accepted: 26 October 2021

Published: 28 October 2021

Publisher's Note: MDPI stays neutral with regard to jurisdictional claims in published maps and institutional affiliations.

Copyright: (c) 2021 by the authors. Licensee MDPI, Basel, Switzerland. This article is an open access article distributed under the terms and conditions of the Creative Commons Attribution (CC BY) license (https:// creativecommons.org/licenses/by/ $4.0 /)$.

\begin{abstract}
Layered double hydroxides (LDHs) have been successfully applied in surface protection and functionalization of metal materials owing to their special structure, composition, controllability, anion exchange, and other excellent properties. Herein, this review focused on the most common LDH preparation methods on magnesium alloys in the past 10 years by summarizing about 70 research papers. At the same time, based on the corrosion protection mechanism of LDH materials, the performance of LDH films and LDH as filler on metal substrates was briefly introduced. The surface of LDH materials were chemically modified to enhance their compatibility with solvents, and their corrosion resistance function was developed as an additive. Finally, LDH-based composite coatings on $\mathrm{Mg}$ alloys by surface pretreatment and chemical modification were discussed.
\end{abstract}

Keywords: layered double hydroxides; magnesium alloy; corrosion protection; composite coating

\section{Introduction}

Magnesium $(\mathrm{Mg})$ and its alloys, known as the lightest metal structural materials, are widely applied in the computer, electronics, automotive, and aerospace industries due to their advantages (including their low specific gravity, high specific strength and stiffness, processing, and recycling) [1-3]. The overall weight of a car is reduced by $10 \%$ and the fuel is economized by about $20 \%-30 \%$ with no significant design changes through using magnesium alloys [4]. In addition, the elastic modulus of magnesium alloys is similar to that of the human skeleton, which can relieve external stress and represent the major component of artificial skeletons. Therefore, as a medical material, magnesium alloys are ideal materials for cartilage repair and metal implantation [5,6]. Although magnesium alloys have many excellent properties, their inferior corrosion resistance due to the low standard potential $(-2.36 \mathrm{~V})$ limits their further development and extensive applications [7]. Hence, research on corrosion resistance of magnesium alloys is an important topic for their wide application. In the past few decades, plenty of approaches have been used to combat the corrosion of $\mathrm{Mg}$ alloys including alloying, improved heat treatment process, and advanced surface treatment technology. Among them, surface treatment technology is the most extensive and effective method, including chemical conversion coatings, polymer coatings, micro-arc oxidation (MAO), layer-by-layer film, and LDH coatings.

In recent years, LDHs have gained a key position not only due to environmentally friendly and low cost but more importantly due to their the high anionic exchange capability [8]. As a result, intercalated materials have shown broad application prospects as corrosion resistant coatings.

LDH is a type of hydrotalcite-like materials, composed of two or more metallic elements, with a layered structure of hydroxide [9]. The first studies of hydrotalcite com- 
pounds can be traced back to 1842, a natural deposit from Norway was discovered by Hochstetter [10]. However, it was not until Manasse (1915) and Frondel (1941) that the structure of hydrotalcite was understood. In 1942, Feitknecht first proposed the idea of a double-layer structure and synthesized LDH by mixing a metal salt solution with an alkali metal hydroxide LDH [11]. LDHs consist of positive-charged laminae of mixed metal ion $\mathrm{M}^{3+} /\left(\mathrm{M}^{2+}+\mathrm{M}^{3+}\right)$ hydroxide layers, anions with water molecules among the layers. As depicted in Figure 1, the general crystal structure of LDH films is $\left[\mathrm{M}^{2+}{ }_{1-\mathrm{x}}\right.$ $\left.\mathrm{M}^{3+}{ }_{\mathrm{x}}(\mathrm{OH})_{2}\right]^{\mathrm{x}+}\left(\mathrm{A}^{\mathrm{m}-}\right)_{\mathrm{x} / \mathrm{m}} \cdot \mathrm{nH}_{2} \mathrm{O}$, where $\mathrm{M}^{2+}$ refers to metal cations (e.g., $\mathrm{Mg}^{2+}, \mathrm{Zn}^{2+}$, $\left.\mathrm{Cu}^{2+}, \mathrm{Ni}^{2+}\right), \mathrm{M}^{3+}$ means trivalent cationic (e.g., $\mathrm{Al}^{3+}, \mathrm{Fe}^{3+}, \mathrm{Cr}^{3+}$ ), $\mathrm{x}$ is the mole ratio of $\mathrm{M}^{3+} /\left(\mathrm{M}^{2+}+\mathrm{M}^{3+}\right)$ and $\mathrm{A}^{\mathrm{m}-}$ is an anion with $\mathrm{m}^{-}$valence [12]; Whereas, layers of hydroxide are studded with water molecules during the synthesis [13]. Basically, the crystal structure, bonding strength and anion exchange capacity of LDH depend on the size and charge of the metal cation, the charge of the anion, and the relative amount of crystal water [14].

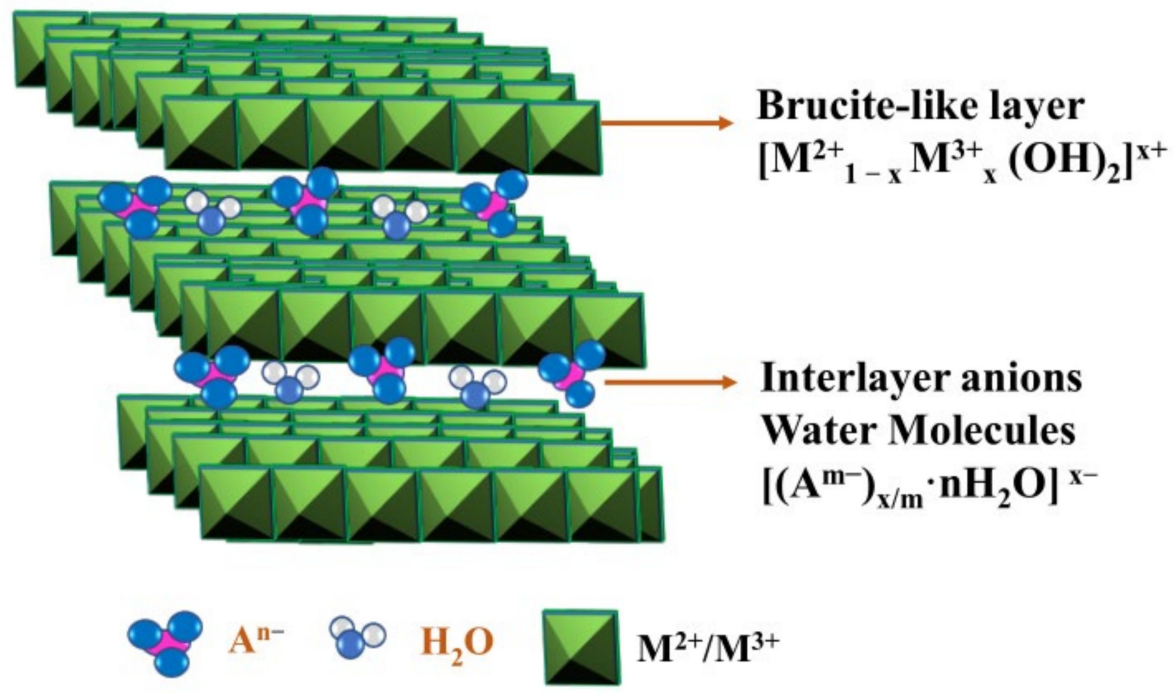

Figure 1. Schematic illustration of LDH structure and chemical component.

LDHs have potential applications in catalysis, functional materials, environmental protection, and biomedicine fields due to their unique memory effect and interlayer anion exchange capacity [15]. Recently, it has been widely used as prepared LDH coatings on alloys due to broad resource of raw material, simple synthesis methods, and synthesis in large quantities, especially on magnesium alloys [16].

The development of LDH can be traced back to recent research. In early 1997, Buchheit et al. [17] developed a number of LDH coatings; in their work, a hydrotalcite protective coating was created and contributed greatly to the progress of in-situ growth methods. Previous works have proven that LDH-based materials could serve as potential adsorbents and catalysts for the purification of dye waste water due to their special anionic exchange capability. Basu et al. [18] reviewed the production progress of LDH materials and based elastomer composites. In recent years, adjusting the composition of LDH to obtain ideal properties, which leading to various application in various industries. Given this, various LDHs and their coatings are prepared on $\mathrm{Mg}$ alloy surface to improve their corrosion resistance. In different types of LDH materials, a double compound consisting of $\mathrm{Mg}-\mathrm{Al} \mathrm{LDH}$ and carbonate as interlayer anions has been widely used in various fields.

At present, surface modification is still the most appropriate strategy to overcome the rapid corrosion of magnesium alloys and improve their performance, especially by adjusting the composition of LDH to obtain better performances. This review focus on describing the recent progress of common methods for preparing $\mathrm{Mg}-\mathrm{Al} \mathrm{LDH}$ coatings on magnesium alloys. In this work, the main fabrication methods are summarized, such as coprecipitation, in-situ growth, hydrothermal synthesis, urea hydrolysis, steam coating, electrochemical 
deposition, rotating coating, and anion exchange reaction. Then the properties of LDH film and its application on metal substrate are introduced from the anticorrosion mechanism of LDH material. The surface chemical modification of LDH material was further analyzed to improve its compatibility with solvent, and the corrosion resistance of LDH material was developed. Finally, we will put forward the current limitations and future development direction from the perspective of application, and make a conclusion.

\section{Synthesis of LDH}

\subsection{Co-Precipitation}

Co-precipitation (CPT) means that under the protection of nitrogen, two or more kinds of soluble salt with the layered structure of metal ions are uniformly mixed, and the corresponding solid particles are obtained through precipitation reaction at an appropriate $\mathrm{pH}$ [18]. The CPT approach is one of the most attractive technique for preparing LDH intercalation materials. Due to the limitation of different $\mathrm{pH}$ values, it is difficult for metal ions such as $\mathrm{Co}, \mathrm{Mn}$, and $\mathrm{Cr}$ to achieve the purpose of co-precipitation under the conditions of $\mathrm{pH}$ values needed for urea decomposition. Therefore, the co-precipitation method is the only suitable for the preparation of $\mathrm{LDH}$ intercalation materials of $\mathrm{Mg}, \mathrm{Al}, \mathrm{Zn}$, and other metals. The combination of CPT and hydrothermal reaction can form LDH coatings of different systems, no matter what the chemical composition of the substrate, the laminates, and the types of anions among the layers are different [19].

Zhang et al. [20] synthetised Mg-Al LDH coating on AZ31 alloy surface through the co-precipitation method and hydrothermal method. The LDH coatings showed extremely lower corrosion current density, which can be regarded as a candidate material for nonchromium chemical conversion coating of $\mathrm{Mg}-\mathrm{Al}$ alloys. As showed in Figure 2, LDH layers are well combined with each other, and no defects are found at the interface. The whole $\mathrm{Mg}-\mathrm{Al} \mathrm{LDH}$ coatings were observed to be smooth and compact, which improves the adhesion of the substrate material and coating. Wu et al. [21] prepared $\mathrm{Mg}-\mathrm{Al} \mathrm{LDH}$ coatings with porous organic surface layer by integrating the co-precipitation technique and hydro-thermal synthesis method for the expanded application of $\mathrm{Mg}$ alloys. This work shows that appropriate addition of polyglutamic acid (PGA) can prolong the corrosion time of the composite coating when the $\mathrm{pH}$ reaches the minimum value, thus the corrosion resistance of AZ31 alloy were improved by the composite coating on the furface.
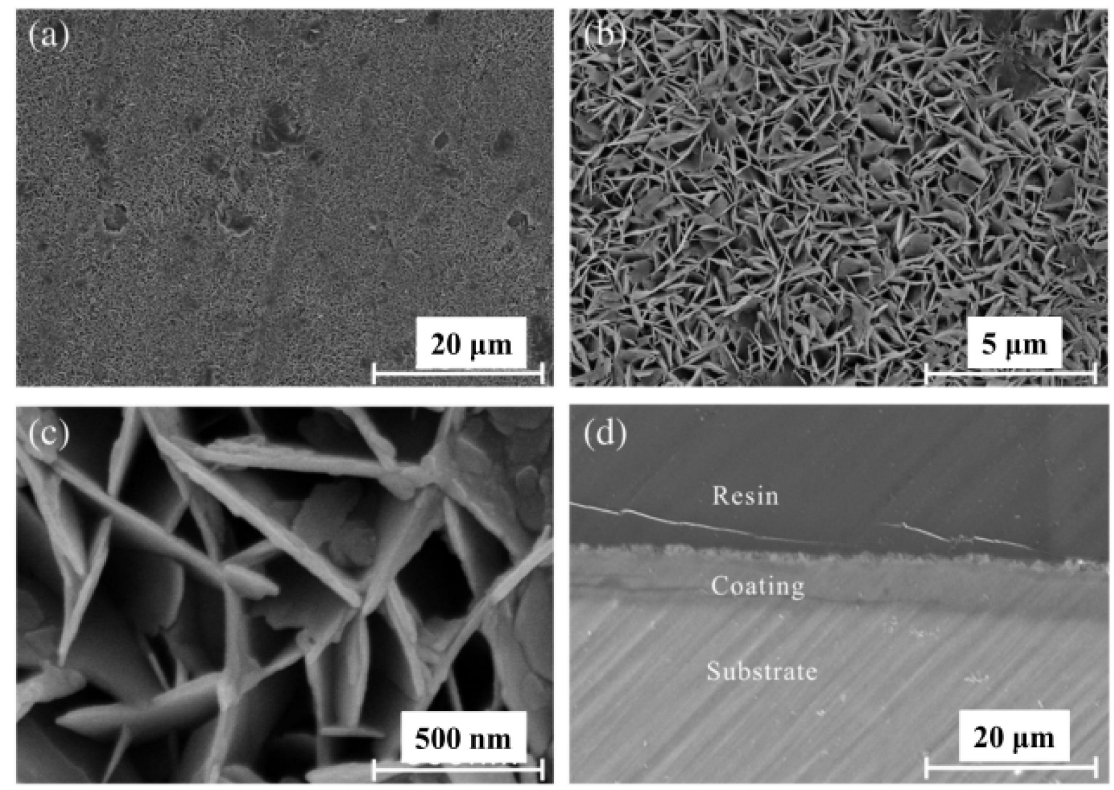

Figure 2. (a-c) The SEM images of the $\mathrm{LDH}$ coating on $\mathrm{Mg}$ alloy with different magnification; (d) the cross-sectional SEM images (crystallization with $48 \mathrm{~h}$ ). Reprinted with permission from [20]; Copyright 2014 Elsevier. 
In general, the precipitated material needs to be heated for several hours at $60-80{ }^{\circ} \mathrm{C}$ to improve the crystallinity of LDH [22]. However, the co-precipitation method has been widely used in the preparation of $\mathrm{LDH}$ powder due to its time consuming and poor adhesion between substrate and coating, which is not suitable for the preparation of coating on metal substrate [23].

\subsection{In-Situ Growth Methods}

The in-situ growth method refers to the selection of a special surface treatment of the metal plate, which directly participates in the reaction and provides metal cationic on the metal substrate to form a film technology. It is considered to be the most promising method due to good adhesion between LDH films and substrate formed by chemical bonds [24]. At present, there are five methods for in-situ growth synthesis of LDH films on Mg alloys.

\subsubsection{One-Step In-Situ Growth Method}

The one-step in-situ growth technique has been regarded as a promising method which can straight synthetize LDH films on the substrate and greatly improve the mechanical properties and adhesion of coating to the substrate. Yang et al. [25] determined that Mg-Al LDH films were first phosphorylated on cellulose microspheres (CMs) and then prepared by in-situ nano-growth. This finding offers a new approach that can not only improve the production and crystallinity of $\mathrm{Mg}-\mathrm{Al} \mathrm{LDH}$ but also improve the load of $\mathrm{Mg}-\mathrm{Al} \mathrm{LDH}$ and the porous structure of CMs, so that $\mathrm{Mg}-\mathrm{Al} \mathrm{LDH} @ \mathrm{CMs}$ are suited for superhydrophobic treatment. Th et al. [26] studied an inhibitor (2-mercapto benzo thiazole, MBT) combined with Mg-Al LDH coatings (Mg-Al LDH/MBT) on AZ31 alloy substrate at comparatively low temperature $\left(95^{\circ} \mathrm{C}\right)$ and environmental pressure by one-step in-situ growth technique. Then, the corrosion protection of the composite coating was evaluated by various testing method. As shown in Figure 3, the corrosion current density of LDH/MBT composite coatings are very low, and even there is no corrosion behavior exposed to $\mathrm{NaCl}$ solution or salt spray environment for 15 days, which proves its good corrosion resistance.

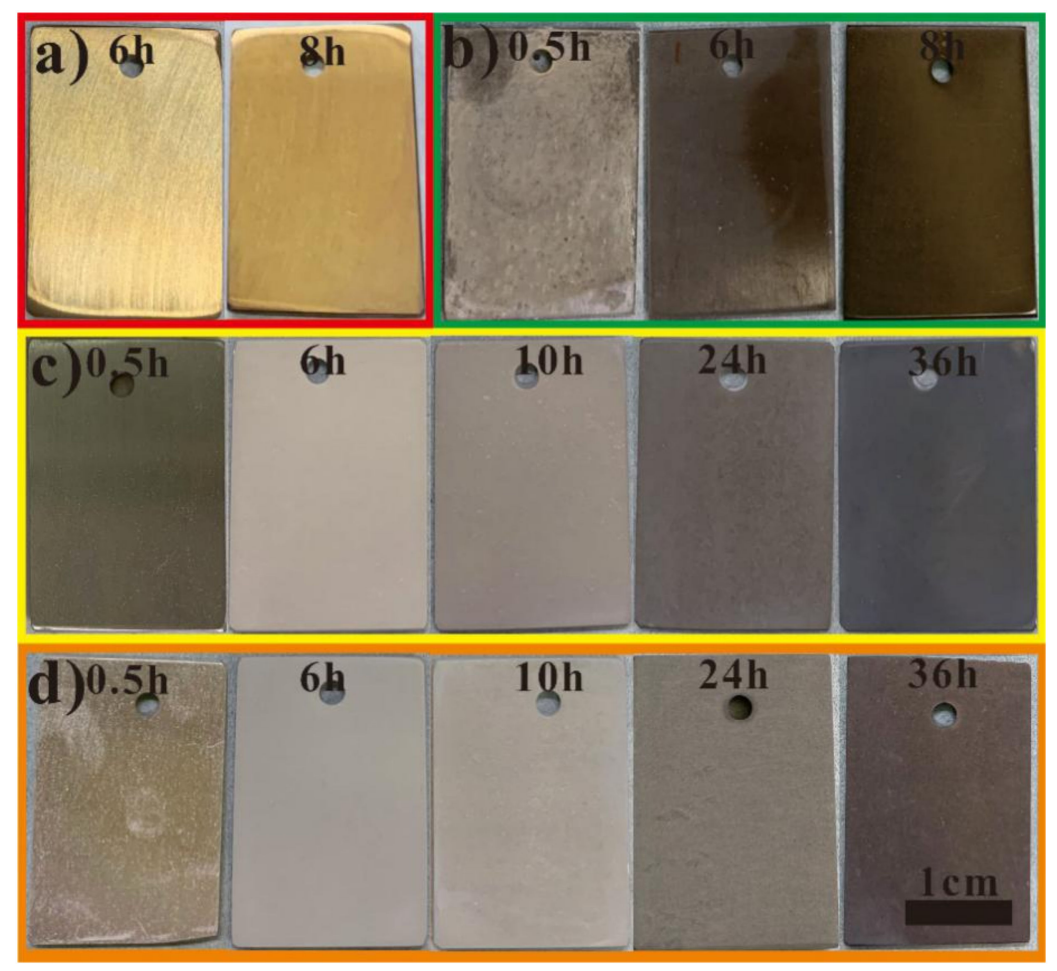

Figure 3. Digital images of (a) blank; (b) MBT; (c) Mg-Al LDHs; and (d) Mg-Al LDHs/MBT films synthetize with various reaction times at $95^{\circ} \mathrm{C}$ and 1 barometric pressure. Reprinted with permission from [26]; Copyright 2021 Elsevier. 
At present, $\mathrm{Mg}-\mathrm{Al} \mathrm{LDH}$ coatings produced through one-step in-situ growth technique on $\mathrm{Mg}$ alloys can solve the adverse effects brought by hydro-thermal method under higher temperatures and higher pressures in the past. However, it is worth noting that this process is merely applicable to $\mathrm{Mg}-\mathrm{Al}$ alloys.

\subsubsection{Two-Step In-Situ Growth Method}

The two-step in-situ growth method consists of two parts: pre-treatment to embed ions into the LDH coatings, and post-treatment to maintain alignment by adding $\mathrm{NaOH}$ solution. Anjumet et al. [27] successfully prepared Mg-Al LDH coatings embedded with 8 hydroxy quinoline ( $8 \mathrm{HQ}$ ) on AZ31 by two-step in-situ growth technique and studied the effect of $8 \mathrm{HQ}$ concentration on morphology and corrosion resistance. The results reveal that the LDH film possessed the function of ion exchange and chelation formation, and the $8 \mathrm{HQ}$ inserted into the layer has stronger corrosion resistance, which can better protect the metal from corrosion. Chen et al. [28] first made uses of the magnesium containing only alpha phase and magnesium alloys (with or without aluminum). After the sample was treated with $\mathrm{NaOH}$ solution, the initial precursor film was obtained and soaked at $80^{\circ} \mathrm{C}$ for $1.5 \mathrm{~h}$ to obtain the final $\mathrm{Mg}-\mathrm{Al} \mathrm{LDH}$ coatings. It was concluded that the two-step in-situ growth approach is also suitable for other $\mathrm{Mg}$ alloys whether or not they contain $\mathrm{Al}$ elements, so long as the process parameters are properly adjusted. Therefore, the corrosion resistance of most $\mathrm{Mg}$ alloys can be improved by the two-step in-situ growth method.

According to the above statement, the in-situ growth method can obtain dense coating under the condition of controlling $\mathrm{pH}$ value, but the process is complicated. In this technique, the substrate is immersed in a solution of metal salts, the alkalis of the solution are added to control the $\mathrm{pH}$ value, and the metal substrate effectively becomes the metal source of the reaction, on which the film grows sacrifices part of the substrate [29]. Therefore, this method is only suitable for preparing LDH films directly on the metal matrix, but not for preparing LDH powder/particles.

\subsubsection{Hydrothermal Treatment}

Hydrothermal treatment method refers to the LDH obtained by mixing metal oxides or metal hydroxides with an alkaline solution in a high-pressure reactor for a period of time under certain temperature and pressure conditions. Yttrium-doped Mg-Al-Y LDH films reported by Yao et al. [30] revealed that $\mathrm{Y}$ ions perfectly inserted into the $\mathrm{Mg}-\mathrm{Al}$ LDH by substitution, which not only enhance the corrosion resistance of the coating, but also makes the coating having the ability of self-repair. A new approach for composite coating on $\mathrm{Mg}$ alloy was designed by Li et al. [31]. As shown in Figure 4, the closed porosity of LDH layer and the absorption capacity of chloride ion limit the penetration of corrosive $\mathrm{Cl}^{-}$, and provide effective anti-corrosion protection for oxide film coating. Liao et al. [32] prepared $\mathrm{Mg}-\mathrm{Al}-\mathrm{CO}_{3} \mathrm{LDH}$ through hydrothermal synthesis using $\mathrm{MgO}$ and $\mathrm{Al}_{2} \mathrm{O}_{3}$. It was found that $\mathrm{LDH}$ with good crystallinity could be obtained at $100{ }^{\circ} \mathrm{C}$. With the increase of temperature, the composition of brucite and bauxite in the reaction product increased gradually.

LDH is typically prepared by placing two mixed oxides in an autoclave with deionized water (DI) at $140{ }^{\circ} \mathrm{C}$ for several days [33]. Consequently, the main advantages of hydrothermal synthesis are a completely crystalline structure, obviously layered structure, and uniform grain size distribution of LDH [34]. However, it is worth noting that this method is suitable for use at high temperatures. 


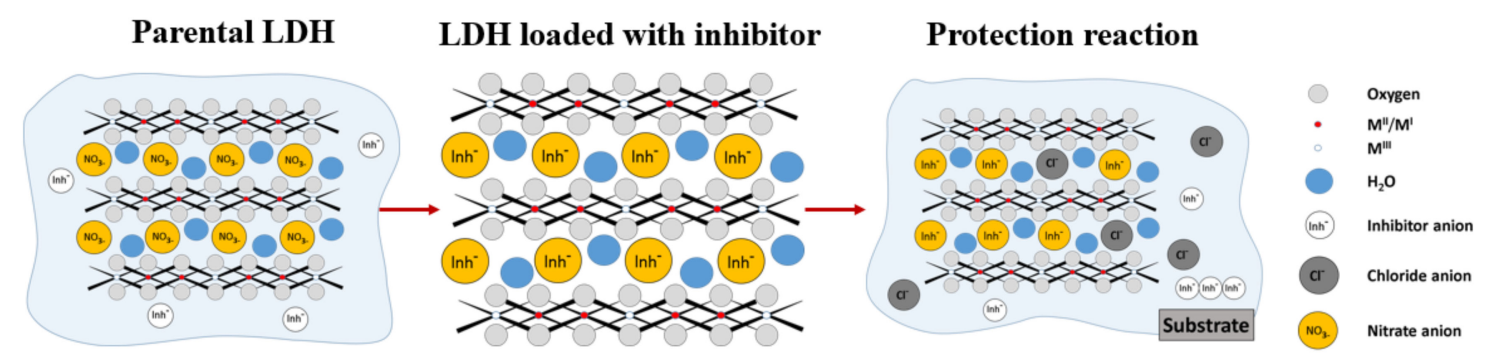

Figure 4. The schematic presentation of LDH structure, the anionic exchange with inhibitor ion, and their triggered release for corrosion protection. Adapted with permission from [34]; Copyright 2020 Elsevier.

\subsubsection{Urea Hydrolysis}

Urea is a kind of base with high solubility in water; it is easy to control the hydrolysis rate. It can generate ammonium hydroxide by hydrolysis in water, while $\mathrm{CO}_{3}{ }^{2-}$ generated by hydrolysis can be used as interlayer anion for the synthesis of LDH in alkaline environment [35]. By controlling the hydrothermal conditions, Hibino et al. [36] synthesized $\mathrm{Mg}-\mathrm{Al} \mathrm{LDH}$ on $\mathrm{Mg}$ alloy using urea hydrolysis reaction. The advantage of this method is that the synthesized LDH has a high crystallization and large volume. However, when the $\mathrm{Mg} / \mathrm{Al}$ ratio of the product in the initial solution with high concentration of metal ions reaches about two, the by-product will be produced, which means that there are the hydrated magnesium hydroxide phases. Zeng et al. [37] used the urea hydrolysis method to grow nano-sized LDH conversion films in-situ on AZ31 alloy. As shown in Figure 5, the dissolved $\mathrm{Mg}^{2+}$ in the precursor membrane is composed of $\mathrm{MgCO}_{3}$ and $\mathrm{Mg}_{5}\left(\mathrm{CO}_{3}\right)_{4}(\mathrm{OH})_{2} \cdot 4 \mathrm{H}_{2} \mathrm{O}$ based on the mechanism of membrane formation. Secondly, the precursor is converted to crystallized $\mathrm{Mg}(\mathrm{OH})_{2}$ under alkaline conditions. In the end, a more stable LDH structure with $\mathrm{Al}^{3+}$ in place of $\mathrm{Mg}^{2+}$ in $\mathrm{Mg}(\mathrm{OH})_{2}$ was obtained. It was found that the nanostructure and ion exchange capacity of $\mathrm{LDH}$ can dramatically improve the corrosion protection of the AZ31 alloy.

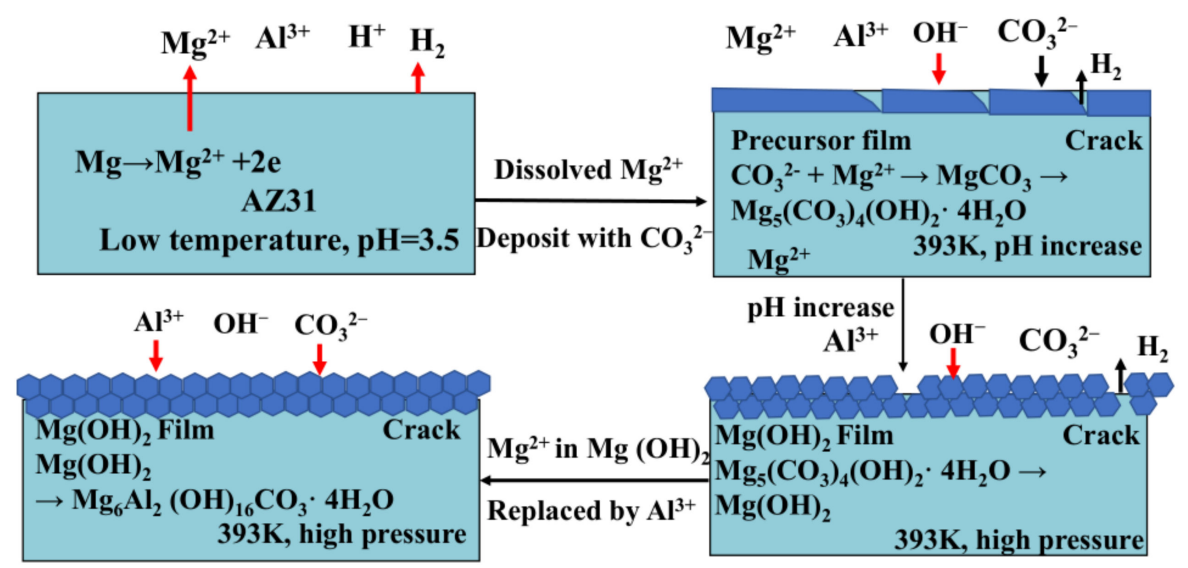

Figure 5. Schematic diagram of $\mathrm{Mg}-\mathrm{Al} \mathrm{LDH}$ film. Adapted with permission from [37]; Copyright 20215 Elsevier.

Thus, a lot of similar findings display that urea hydrolysis can get good crystallization, bulky LDH films and product, but tended to produce by-products, and $\mathrm{M}^{2+}$ or $\mathrm{M}^{3+}$ could be consumed during the by-product formation process, leaving the number of LDHs following formation lower than usual [38].

\subsubsection{Steam Coating}

Steam coating is a method of preparing magnesium alloy anticorrosive coating without chemical steam using ultra-pure water as steam source. Ishizaki et al. [39] reported that protective $\mathrm{Mg}-\mathrm{Al} \mathrm{LDH}$ was produced on magnesium alloys through chemical-steam 
coating, which is a simple, environmentally friendly, and inexpensive method. As shown in Figure 6, XRD analysis shows that Mg-Al LDH films have been successfully prepared. Corrosion experiments also show that the film has a good effect of protecting the substrate. Ishizaki et al. [40] obtained $\mathrm{Mg}(\mathrm{OH})_{2}$ and $\mathrm{Mg}-\mathrm{Al} \mathrm{LDH}$ on $\mathrm{Mg}-\mathrm{Al}$ alloy at $160{ }^{\circ} \mathrm{C}$ with 3-9 $\mathrm{h}$ exploiting aluminum nitrate $\left(\mathrm{Al}\left(\mathrm{NO}_{3}\right)_{3} \cdot 9 \mathrm{H}_{2} \mathrm{O}\right)$ aqueous solution as the vapor source by steam coating method.
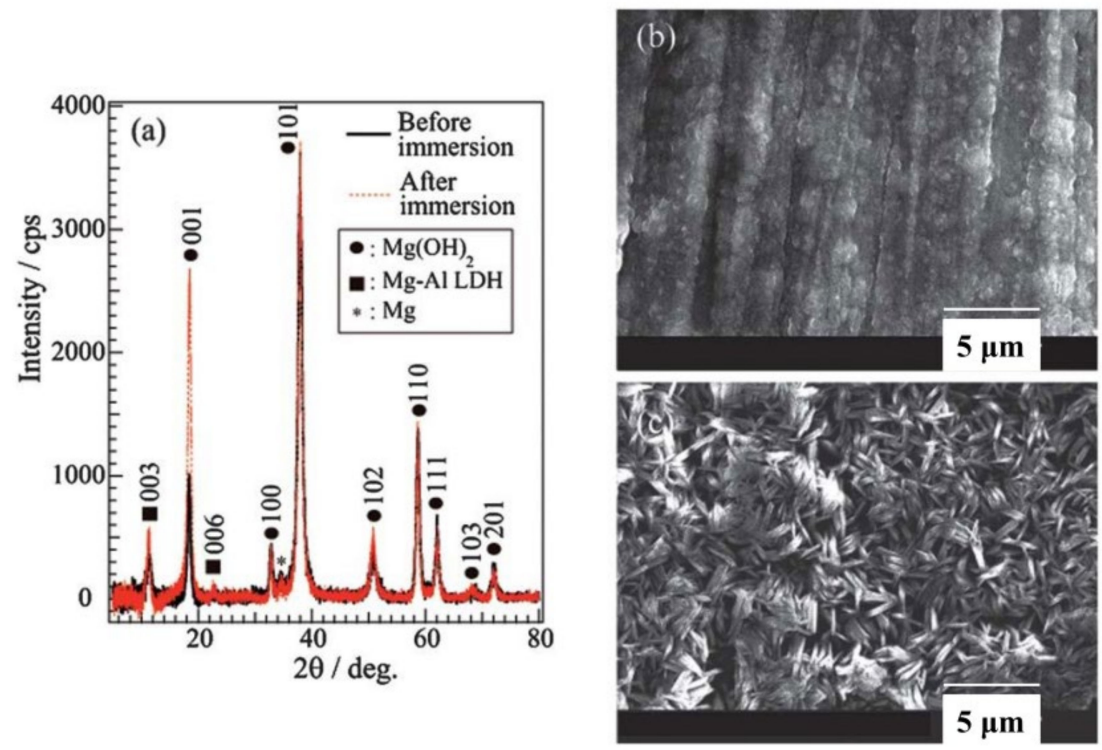

Figure 6. (a) XRD patterns of the sample with various treatment, SEM graphics of the film coated AZ31 (b) before and (c) after immersion. Reprinted with permission from [39]; Copyright 2013 Royal Society of Chemistry.

The advantage of steam coating in contrast to other methods is that it can directly grow the film on the matrix material, and the adhesion between the two is good. Meanwhile, the corrosion protection of the composite film can be enhanced by increasing the Al content in the composite film. However, the main disadvantage of steam coating is that it limits the types of LDH cationic and the extremely high temperature required for the reaction [41].

\subsection{Electrochemical Deposition}

Electrochemical deposition can be seen as a valid method to produce LDH films, which has the advantages of high purity, fast deposition speed, and simple equipment. Wu et al. [42] produced Mg-Al LDH coatings on AZ31 magnesium alloy by electrochemical deposition. In particular, on behalf of dealing with $\mathrm{LDH}$ macropores, $\mathrm{Al}_{2} \mathrm{O}_{3}$ nanoparticles were grown on the coating by electrochemical deposition. The $\mathrm{Mg}-\mathrm{Al} \mathrm{LDH}$ film with nitrate is homogeneous and tight, thinner than that of Li-Al LDH film, but there are some small defects and cracks. Potentiodynamic polarization and EIS measurements demonstrated that the corrosion proctetion of LDH-coated magnesium alloy is better than that of magnesium alloy without coatings in $3.5 \mathrm{wt}$ \% $\mathrm{NaCl}$ solutions. However, the electrochemical deposition method is more expensive and complicated than the above methods [43].

\subsection{Spinning Coating}

Spinning coating is another way of preparing regenerative smooth film, and the advantages of this method are that it is environment-friendly, provides excellent adhesion between film and substrate, uniform film formation, and achieves good micro-concave and convex structure on the surface. LDH films with good corrosion protection and bonding can be prepared through a simple process. Zhang et al. [44] combined LDH films on AZ31 $\mathrm{Mg}$ alloy through rotating coating method using aqueous solution as the vapor source. The obtained film surface is uniform, and the electrochemical polarization curve of the film after 
coating for $7 \mathrm{~h}$ shows very low corrosion current density, which is much lower than that of AZ31 magnesium alloy without coating. The fantastic anticorrosive performance of LDH films on $\mathrm{Mg}$ alloys is obtained through spinning coating technology, since the infiltration of erosive ions is limited and therefore the corrosion of matrix is inhibited. Nevertheless, this method is not suitable for the substrates with complicated shape, and the protective action is also reduced due to the thin coatings [45].

\subsection{Anion-Exchange}

The anion-exchange method derives from the intracellular anion exchange feature of $\mathrm{LDH}$, which not only maintains the original lamellar structure of $\mathrm{LDH}$, but also selects the type of intracellular anions. Kim et al. [46] used anion exchange method to insert diacrylic acid and pvinyl benzoic acid into the LDH interlayer, and realized the polymerization of organic molecules in the LDH interlayer. The corrosion inhibition anions can be delivered slowly, and the corrosive media also can be adsorbed, owing to the LDHs produced by this method, so that the matrix is double-protected. Therefore, $\mathrm{Cl}^{-}$or $\mathrm{NO}_{3}{ }^{-}$intercalation $\mathrm{LDH}$ is often used as the precursor to obtain some special composition of LDH materials through ion exchange reaction. Chen et al. [47] prepared $\mathrm{Mg}-\mathrm{Al} \mathrm{LDH}$ on AZ31 magnesium alloy and studied the corrosion mechanism of $\mathrm{Mg}-\mathrm{Al}-\mathrm{CO}_{3}{ }^{2-} \mathrm{LDH}$. As showed in Figure 7, it can be seen that the surface of the matrix is completely overlapped with tight and falculate lamina, the coating is dense, smooth, and has almost no micro-cracks. Nevertheless, this method is demanding and the degree of crystallinity of the LDH is smaller than that of before-mentioned methods [48].

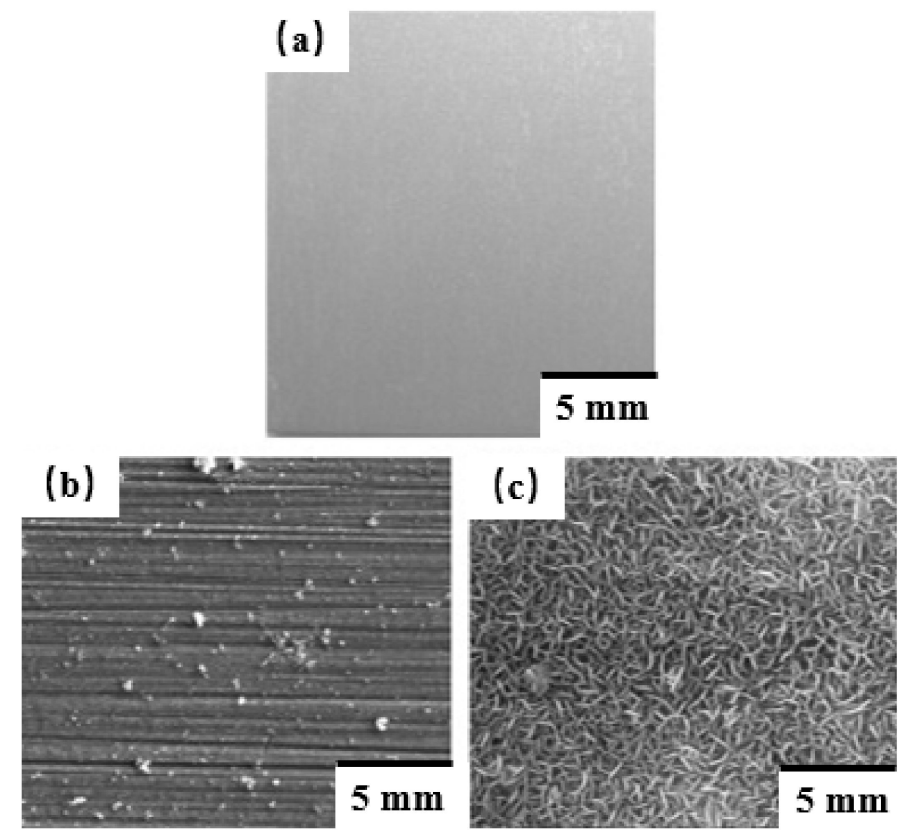

Figure 7. Images of the LDH film: (a) optical miscrostructure; SEM images with low magnification (b), and (c) high magnification. Reprinted with permission from [47].; Copyright 2012 Elsevier.

To sum up, although significant progress has been made in the preparation of $\mathrm{Mg}-\mathrm{Al}$ LDH films on AZ31 Mg alloy surfaces, two major challenges remain to be considered when combining the advantages and disadvantages of each method. The first is how to make the size and specific surface area of LDH film adjustable. The second is that it is necessary to improve the service life of metal materials in large quantities, reduce the damage of corrosion products to products, and increase the application of corrosion protection in various engineering fields. 


\section{The Anti-Corrosion Mechanisms}

For the past few years, LDH films are regarded as the next potential generation coating for magnesium alloys due to their stable lamellar structure and adjustable international anions, which can not only provide protection for the metal matrix but also absorb corrosive ions. The corrosion properties and corrosion resistance mechanism of LDH materials were investigate intensively [49].

\subsection{Interlayer Anion Exchange Mechanism}

LDHs are the best nanotube for corrosion inhibitor due to their stable layered structure, high efficiency, low cost, and simple operation. Adding only minor trace quantities of chemical substances to the corrosive medium through physical or chemistry reaction, which can slow down the speed of metal corrosion and keep the physical, the chemical properties of the metal unchanged. Interlamellar anion exchangeability is an important property of LDH, and its interlamellar anions can swap with various anions for obtaining materials with different functions [50].

Owing to the anion-exchange ability between LDH layers, it is an effective way for intercalating corrosion inhibitor into the protective layer with lamellar structure to obtain high corrosion protection of the substrate. Chen et al. [51] prepared corrosion inhibitor on AZ31 Mg alloy inserting aspartic acid (ASP) into Mg-Al LDH by one-step hydrothermal method. Resulting from the maximum porosity coverage rate and the lamellar nanostructure, $\mathrm{Mg}-\mathrm{Al}-\mathrm{ASP} \mathrm{LDH}$ has a good corrosion inhibition performance and a higher specific surface area to insert invasive anionic species such as $\mathrm{Cl}^{-}$. Hence, it is an effective anticorrosive and environmentally friendly conversion coating for light metals and alloys. Zhang et al. [52] prepared nitrate-containing LDH in situ on Mg alloys with low $\mathrm{Al}$ content without introducing additional trivalent metal salts by using an anode film composed of $\mathrm{Mg}-\mathrm{Al}$ mixed oxide $\left(\mathrm{MgAl}_{2} \mathrm{O}_{4}\right.$ spinel) as an internal source. Then, vanadate inhibitor anions were inserted into the interlayer channel of LDH through anion exchange process. It can be seen that $\mathrm{VO}_{3}{ }^{-}$is beneficial to the protection of anode film and $\mathrm{LDH}$ $\mathrm{NO}_{3}{ }^{-}$under corrosion conditions due to the value of icorr $=5.1 \times 10^{-7} \mathrm{~A} \mathrm{~cm}^{-2}$ also higher than that of $\mathrm{LDH} \mathrm{VO}_{3}{ }^{-}$. Although different corrosion inhibitor anions are inserted into LDH films according to the principle of anion exchange, only part of the anions show a high affinity for the lamellar structure. In order to prepare more stable LDH films with lamellar structure, Miyata obtained from the experiment that the anion exchange order in $\mathrm{LDH}$ intercalation is: $\mathrm{CO}_{3}{ }^{2-}>\mathrm{SO}_{4}{ }^{2-}>\mathrm{OH}^{-}>\mathrm{F}^{-}>\mathrm{Cl}^{-}>\mathrm{Br}^{-}>\mathrm{NO}_{3}{ }^{-}$. High-priced anions are easy to be exchanged into LDH materials, while low-priced anions are easy to be exchanged out. Therefore, in order to synthesize some special LDH materials, chloride ion or nitrate ion intercalation is often used, and LDH is obtained through ion exchange reaction as the precursor [53]. LDHs can be used as an effective component to inhibit the corrosion reaction of corrosive ions entering its interlayer, meanwhile LDH interlayer exchange corrosion inhibitor can also protect the matrix metal material from local corrosion.

In summary, LDH protects metal groups by physical barrier, anion exchange mechanism and surface modification. In other words, LDHs generally use physical barriers on the surface of the metal matrix to block the aggressive anions, so as to reduce the interaction between the substrate and the aggressive ions. In addition, LDH can also exchange and intercalate anions with electrolytes, and improve the protection of metal matrix by surface modification with organic solvents.

\subsection{Composite Synergistic Corrosion Resistance Mechanisms}

In recent years, water-borne epoxy resins have been considered as effective adhesives, coatings and compound substrates due to their good adhesion, stable chemical properties and good corrosion resistance. However, in the process of high temperature curing, waterborne epoxy resins can generate numerous micro-pores, which will allow the external corrosive media to penetrate into the protective matrix material, which severely restrict the wider application of waterborne epoxy resin [54]. Hayatdawoudi et al. [55] dispersed 
scale inhibitor-intercalated LDH nanocontainers in a zinc-rich epoxy resin (ZRE) film. The effect of LDH nanocontainers on the protective properties of ZRE films was also studied. It was noticed that adding LDH nanocontainer into ZRE film can catch corrosive $\mathrm{Cl}^{-}$and liberate appropriate substances, so the carbon steel matrix has a stronger corrosion inhibition performance. Secondly, due to the two-dimensional layered structure of LDH, their structure can block some holes in the coating, so as to effectively restrain permeation of corrosive ions in the film and improve the corrosion resistance of the matrix material. The ZRE intercalated LDH nanocontainers exhibit a blocking effect, sacrificing cathodic protection and intelligent inhibition in the curve area of the epoxy zinc-rich coating and reducing the local corrosion of zinc particles.

Graphene can effectively restrain oxygen and water molecules from diffusing into the surface of metal-based materials owing to the particular layered structure. The synergistic effect of adding other nano-materials and LDH interlayer inhibitor ions into graphite composites can enhance the corrosion protection of LDH films. Chen et al. [56] deposited graphene-modified LDH nanocephalic films on the surface of $\mathrm{Mg}$ alloy using a two-step method, and then studied the structure, morphology and composition of LDH/Graphene films. Experimental results showed that the modified Graphene layer can seal the pores of the nest-like LDH films, making LDH films have hydrophobicity (CA 127.8 ) and enhance corrosion resistance, which can enhance the corrosion protection of the metal matrix. The synergistic action of the impermeable inert Graphene layer and the LDH substrate films loaded with active inhibitors give better anticorrosion performance of the composite films.

At present, organic coating is one of the most common and effective methods for metal protective coating. The corrosion inhibitor is directly mixed with the organic coating that allow the corrosive ions from the outside to invade into the metal matrix, and even cause the loss of corrosion inhibitor activity. Due to the particularity of the layered structure of LDH and its anion exchange performance, the direct contact between the inhibitor and the organic coating can be effectively avoided. Therefore, the addition of a corrosion inhibitor such as LDH into the organic coating can effectively increase the protection of the coating to the metal materials. Zhang et al. [57] prepared phytic acid (PA) composite coating with Ce salt sealing on Mg alloy surface by plasma electrolytic oxidation and hydrothermal synthesis. The corrosion protection and self-healing ability were studied by polarization curve, EIS, immersion test, and SVET. The $\mathrm{E}_{\text {corr }}$ and $\mathrm{i}_{\text {corr }}$ values for PEO were $-0.46 \mathrm{~V}_{\mathrm{SCE}}$ and $2.31 \mu \mathrm{A} \cdot \mathrm{cm}^{-2}$, respectively. This is due to the synergistic effect of Ce and phosphate and the optimum anticorrosion performance of PA modified composite coating on magnesium alloy. Chen et al. [58] produced Mg-Al-PA LDH by embedding phytic acid (PA), an environmentally friendly corrosion inhibitor-intercalated acid into the synthesized $\mathrm{Mg}-\mathrm{Al}-\mathrm{CO}_{3}{ }^{2-} \mathrm{LDH}$ coatings to obtain the synergistic protection by metal chelating ability, Mg-Al-PA LDH has good stability and lasting protection effect on metal matrix. Nitrite is generally considered to be the most effective anodic inhibitor embedded in concrete, but its potential toxicity to humans and the environment limits its application in corrosion protection. To reduce these harmful effects, a novel multifunctional inhibitor of $\mathrm{Mg}-\mathrm{Al} \mathrm{LDH}$ loading with nitrite anions was produced through a calcination-rehydration in air. $\mathrm{Mg}-\mathrm{Al}-\mathrm{NO}_{3} \mathrm{LDH}$ effectively reduces the toxicity of nitrites compared to adding nitrites directly to concrete and hide nitrites in the structure, preventing their release into the environment from the concrete structure. After the concrete construction is finished, the effective nitrite can be discharged. In other words, nitrite can undergo anion exchange reaction and be released when the oxide permeates the concrete internal environment.

LDH materials have been widely used in organic coatings and concrete due to its good barrier property of two-dimensional layered structure. On the one hand, it can extend the diffusion path of corrosive media, and on the other hand it can fill the microholes in the coating, reducing the generation of defects. Nevertheless, as a class of inorganic clay compounds, LDHs will show hydrophilicity and the compatibility with organic solvents will be poor, which speed up the corrosion rate. Therefore, it is necessary to modify LDH appropriately to improve its compatibility with organic polymers. 


\section{LDH Modified Coating on Magnesium Alloy}

LDHs grow directly on the metal substrate by forming chemical bonds through in situ growth technology, so that there is a strong adhesion between LDH films and the metal matrix. On the other hand, the use of in-situ growth results in the alignment of LDH perpendicular to the substrate, resulting in crystals with different crystal orientation. This orientation of the film is generally associated with crystallization defects and the formation of corrosion channels. Therefore, in order to maximize corrosion resistance life of LDH films, anion-exchange and surface modification are often used to obtain better corrosion resistance and super-hydrophobic properties.

\subsection{Anticorrosive Intercalated Structure}

The LDH films have good corrosion protection owing to its anion-exchange capacity and special layered structure, which decelerate the corrosion rate of Mg alloy [59]. Compared to the common coatings, LDHs nanosheets typically grow perpendicular to the surface of the substrate, and there are many pores between the layers, providing diffusion paths for anion exchange [60,61]. In addition, different anionic intercalation structure can confer different protective effects of LDH on magnesium alloys. Therefore, a discussion of the effects of different anionic intercalation structures on the corrosion resistance of LDH films will be presented in detail below.

Wu et al. [62] used in situ hydrothermal method to grow $\mathrm{Mg}-\mathrm{Al} \mathrm{LDH}$ on the surface of AZ31 alloy, followed by vanadate intercalation reactions to produce $\mathrm{Mg}-\mathrm{Al}-\mathrm{V}_{2} \mathrm{O}_{7}{ }^{4-}$ $\mathrm{LDH}$ coatings. Kameda et al. [63] studied $\mathrm{Mg}-\mathrm{Al} \mathrm{LDH}$ intercalated with $\mathrm{CO}_{3}{ }^{2-}$ as a reusable adsorbent with anion exchange capacity, which has been used to remove $\mathrm{HCl}, \mathrm{SO}_{2}$, and $\mathrm{NO}_{\mathrm{x}}$. Table 1 illustrated the values of corrosion current density ( $\left.\mathrm{i}_{\text {corr }}\right)$ and corrosion potential $\left(\mathrm{E}_{\mathrm{corr}}\right)$ of the samples in $3.5 \mathrm{wt} . \% \mathrm{NaCl}$ solution.

Table 1. Corrosion potential $\left(\mathrm{E}_{\mathrm{corr}}\right)$, corrosion current density $\left(\mathrm{I}_{\mathrm{corr}}\right)$ of the samples in $3.5 \mathrm{wt} . \%$ $\mathrm{NaCl}$ solution.

\begin{tabular}{cccc}
\hline Sample & Electrolyte & $\mathbf{E}_{\text {corr }}(\mathbf{V} / \mathbf{S C E})$ & $\mathbf{I}_{\text {corr }}\left(\boldsymbol{\mu} \mathbf{A c m}^{-\mathbf{2}}\right)$ \\
\hline $\mathrm{CO}_{3} \cdot \mathrm{Mg}-\mathrm{Al} \mathrm{LDH}$ & $3.5 \mathrm{wt} . \% \mathrm{NaCl}$ & -0.805 & $1.13 \times 10^{-7}$ \\
$\mathrm{Cl} \cdot \mathrm{Mg}-\mathrm{Al} \mathrm{LDH}$ & $3.5 \mathrm{wt} . \% \mathrm{NaCl}$ & -1.300 & $2.52 \times 10^{-7}$ \\
$\mathrm{NO}_{3} \cdot \mathrm{Mg}-\mathrm{Al} \mathrm{LDH}$ & $3.5 \mathrm{wt} . \% \mathrm{NaCl}$ & -1.357 & $5.580 \times 10^{-7}$ \\
$\mathrm{~V}_{2} \mathrm{O}_{7} \cdot \mathrm{Mg}-\mathrm{Al} \mathrm{LDH}$ & $3.5 \mathrm{wt} . \% \mathrm{NaCl}$ & -0.92 & $1.30 \times 10^{-8}$ \\
\hline
\end{tabular}

In general, a larger $\mathrm{E}_{\text {corr }}$ and a smaller $\mathrm{i}_{\text {corr }}$ can inhibit corrosion in terms of thermodynamics and kinetics conditions. As the table shows, the corrosion protection is successively in the same sodium chloride solution: $\mathrm{CO}_{3}{ }^{2-}>\mathrm{V}_{2} \mathrm{O}_{7}{ }^{4-}>\mathrm{Cl}^{-}>\mathrm{NO}_{3}{ }^{-}$. Among these coatings, it is noted that the $\mathrm{i}_{\text {corr }}$ of the $\mathrm{MgAl}-\mathrm{CO}_{3}{ }^{2-} \mathrm{LDH}$ coatings is four orders of magnitude lower than that of the $\mathrm{MgAl}-\mathrm{NO}_{3}{ }^{-} \mathrm{LDH}$ coatings, and zero to two orders of magnitude lower than that of other LDH coatings. It is worth noting that in some high temperature superconducting materials, thin films have stronger anion exchange ability to capture chloride ions in corrosion solution and enhance the corrosion protection of magnesium alloys. Therefore, the thickness and density of the coating are usually also key factors affecting the corrosion resistance, since they can limit the direct contact between the matrix and the corrosive medium.

Hence, based on the excellent anion exchange ability and special lamellar structure of $\mathrm{LDH}$, this intercalation process is effective and time-saving in anticorrosion protection. From the perspective of the application of $\mathrm{LDH}$ films on Mg alloys, loading inorganic anions into LDH films is an optimal and effective method of corrosion protection, but if the inhibitor anions can be directly inserted into LDH, additional ion-exchange steps will be reduced. 


\subsection{Super-Hydrophobic Modification}

Biologists have found that the lotus is a self-cleaning plant and have linked its selfcleaning mechanism to a microscopic morphology of its superhydrophobic surface. They found that the superhydrophobic properties of the lotus leaf surface are due to a certain roughness on the nanoscale surface [64]. Inspired by the 'lotus effect', scholars began to prepare artificial hydrophobic coating on metal surface to gain uneven surface materials with small surface energy, so as to achieve the purpose of the super hydrophobic.

Wang et al. [16] produced the corrosion inhibitors intercalated $\mathrm{Mg}-\mathrm{Al} \mathrm{LDH}$ films on magnesium alloys by in-situ growth method, and studied the effect of multi-component synergistic effects, such as molybdate intercalation and lauric acid low surface modification, on the corrosion protection of the films. This finding shows that the film modified by lauric acid has good hydrophobic protection (CA 148.6 $6^{\circ}$. Electrochemical measurement displayed that the superhydrophobic LDH coatings significantly reduce the corrosion current density, which prove that the corrosion protection of $\mathrm{Mg}$ alloy can be improved due to the combination effect of molybdate and lauric acid. Wu et al. [65] synthesized $\mathrm{Mg}-\mathrm{Al} \mathrm{LDH}$ films on the AZ31 Mg alloy by modifying in-situ grown method with stearic acid (SA), sodium laurate (SL), myristic acid (MA)and Per Fluoro Decyl Tri Methoxy Silane (PFDTMS). The static contact angles measured are $150.6^{\circ}, 153.7^{\circ}$, and $152^{\circ}$ by the contact Angle tester as showed in Figure 8. The results indicated that the smallest corrosion current density, the most active corrosion potential and the highest impedance modulus were observed for superhydrophobic Mg-Al LDH-PFDTMS, which can significantly reduce the surface energy and enhance the corrosion protection of magnesium alloy.

Zhang et al. [66] prepared $\mathrm{Mg}-\mathrm{Al} \mathrm{LDH}$ by hydrothermal treatment on Al-rich $\mathrm{Mg}$ alloy. The interior is a lethal layer and the top is a uniform surface composed of magnesium aluminum bimetallic hydroxide micro-wafers, which has obtained excellent corrosion resistance in the brine solution. Besides, due to the natural super-hydrophobic phenomena such as the lotus leaf effect, trimming the direction of the top micro-sheet layer by variating the reaction temperature, time, and $\mathrm{pH}$ to obtain hydrophobic surface following the embellishment of silane fluoride. The super-hydrophobic surface exhibits good corrosion protection due to the appearance of trapped cyclone in the tissue, which provided an economic and environmental protection method for controlling of pre-corrosion products of Mg alloys.

Thus, it is concluded that the surface of the superhydrophobic film is not easy to infiltrate, which can prevent water molecules, $\mathrm{Cl}^{-}$and other corrosive ions from getting to the surface of the matrix to better protect the metal from corrosion.

\subsection{Biocompatible Coatings}

In recent years, biocompatible materials are extensively needed owing to their special excellent abilities and the surface modification on magnesium alloys has attracted more and more attention in particularly due to their better biocompatibility. The biocompatible materials include two types. One is the original biocompatible materials, and the other is the materials that need to be shown biocompatibility through surface modification and other means. 


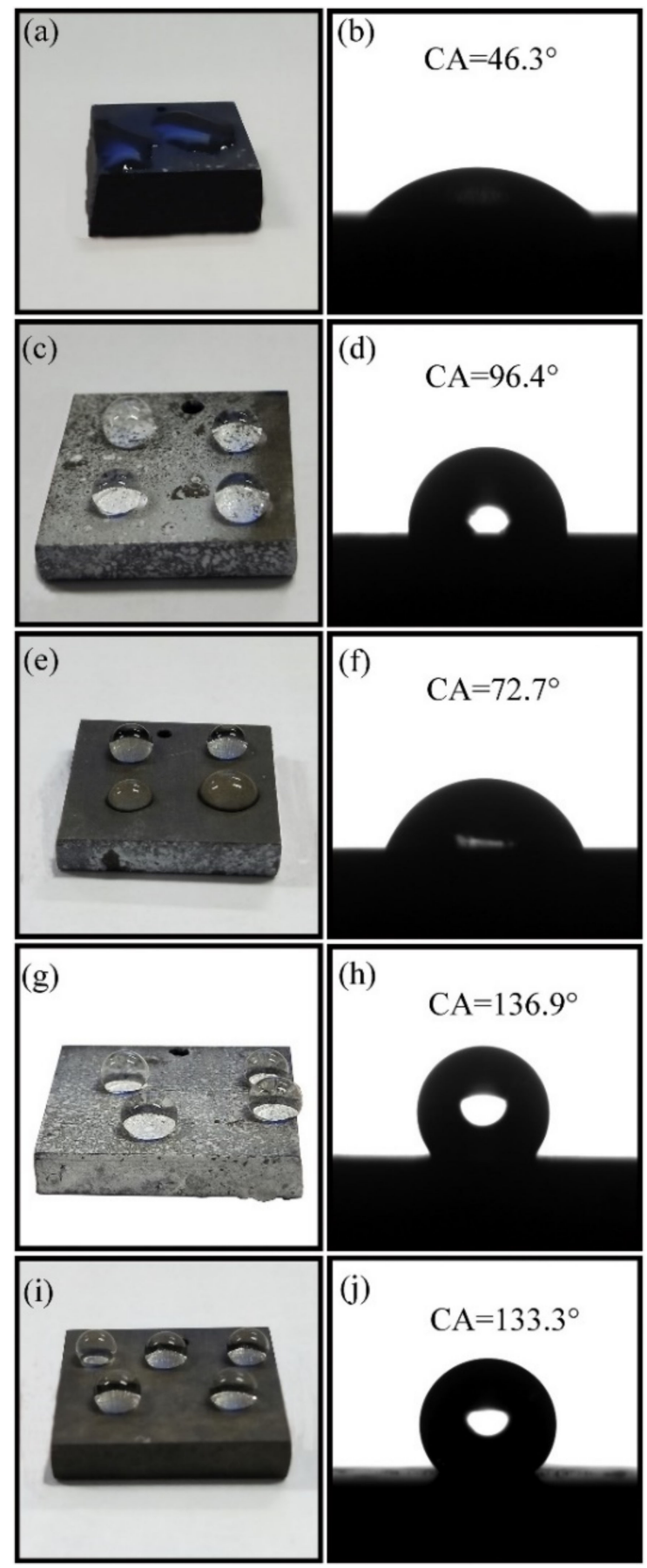

Figure 8. Optical photographs of surface droplets and their corresponding static contact angles: (a,b) Mg-Al LDH; (c,d) SA; (e,f) SL; (g,h) MA; (i,j) PFSTMS. Reprinted with permission from [65]; Copyright 2015 Nature Research.

PVA is one of the most widely used polymer materials at present, which is a biodegradable polymer with fine biocompatibility, stability and chemical resistance. Modified Mg-Al$\mathrm{CO}_{3} \mathrm{LDH}$ with organic acid via co-precipitation method can promote the intercalation of LDH in the polymer matrix, which can obtain a suitable grade of dispersion [67]. In order to promote intercalation in LDH polymer matrix and improve the ideal dispersion, organic diacid was prepared from tetrabromophthalic anhydrides and L-aspartic acid in reflexed acetic acid with pyridine [68]. Under ultrasonic irradiation, the interlayer base spacing of lactate dehydrogenase was modified by organic diacid co-precipitation method, which 
effectively reduced the polymerization time and cohesion of nano-cla. The modification process is shown in the Figure 9, tensile strength and modulus of PVA/mLDH NCs are improved due to hydrogen bonding and the good dispersion of $\mathrm{mLDH}$ in the polymer matrix. Also, due to the biodegradability and biocompatibility of both chiral amino acid dicarboxylic acid and polyvinyl alcohol, hybrid organic-inorganic PVA/modified NCs are considered to be biodegradable, which can be applied in various fields.
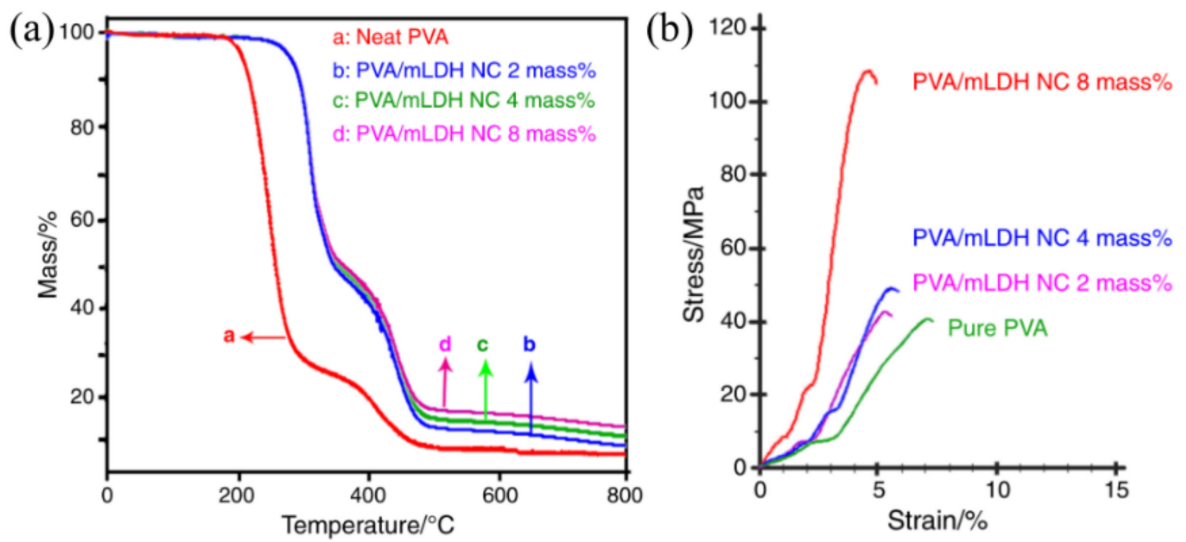

Figure 9. The pure PVA and PVA/mLDH NCs images of (a) TG curve; (b) typical stress-strain diagrams. Reprinted with permission from [68]; Copyright 2017 Elsevier.

On behalf of further expanding the long-range protective effect of absorbable magnesium alloy, Wu et al. [21] prepared PGA sealed Mg-Al LDH coatings on AZ31 magnesium alloy by combining hydrothermal method and vacuum freeze drying method, which synthesized composite coating of LDH and PGA coatings. Electrochemical polarization, impedance spectroscopy and hydrogen evolution tests indicate that the composite coatings effectively provide corrosion protection for AZ31 alloy. In addition, the hybrid coating made mouse embryonic fibroblasts compatible, which improved cell adhesion, migration and proliferation. The composite coating acts as a physical barrier to seal the porous LDH coating, which enhances the corrosion protection of the film and provides long-term protection to the AZ31 substrate. PGA is a kind of synthetic peptide with good hydrophilicity and biodegradability. Zhang et al. [69] synthesized PGA and rose Bengal (RB) conjugate (PGA-RB), which improved the pharmacokinetics and anti-tumor efficacy. In addition, hydrophobic polycaprolactone (PCL) and PGA were used as raw materials to synthesize tissue-engineered menisci with good biomechanical and biodegradable properties. Therefore, Lai et al. [70] successfully applied PGA coating on Mg-Al LDH by hydrothermal treatment, and the results show that $\mathrm{LDH}$ has good corrosion resistance. The cell adhesion study of rat bone marrow stem cells also showed that PGA/LDH coatings can significantly enhance the cell compatibility of substrates, and it has a broad application prospect in orthopedic surgery. Kaseem et al. [71] proposed $\mathrm{WO}_{3}$ nanoparticles to interact with $\mathrm{LDH}$ film through intermolecular hydrogen bond in AZ31 Mg to prepare LDH film by surface modification. This is a novel composite composed of albumin, $\mathrm{WO}_{3}$, and $\mathrm{LDHs}$ film, which can be used for intelligent corrosion protection of magnesium alloys, and it is also an effective strategy to improve the chemical stability of inorganic layers.

Surface modification is the most widely used method to improve the cellular compatibility and corrosion resistance of $\mathrm{Mg}$ alloys. Hence, many researchers only focus on enhancing the corrosion resistance of AZ31 Mg alloys by surface modification to obtain a cellular compatibility surface, ignoring the special requirements of different biomedical applications. Therefore, it is of great significance to develop sufficient bone-bonded magnesium alloy coatings for bone-related applications. 


\section{Summary and Perspectives}

LDH materials have been widely used in the metal protection field due to the rapid development of LDH in anion exchange, preparation technology, modification methods, and corrosion mechanism. However, there are few studies on the mechanism of anion exchange between layers of $\mathrm{LDH}$ and the recombination mechanism of layered structure from the microscopic point of view. In this review, the synthesis methods of LDH coatings have been summarized. The corrosion resistance mechanism of LDH materials on magnesium alloy was briefly discussed. The surface of LDH materials were chemically modified to enhance the compatibility with solvent, and the corrosion resistance function was developed in the form of additives, which summarized the composite coating with special function.

In conclusion, LDH coatings have a good protective effect on magnesium alloy, but there are still problems to be further studied. In-situ growth is the most widely used method, but the degree and thickness of LDH coatings are sometimes inadequate. This indicates the importance of multiple synthesis methods for LDH coatings. The bonding force between $\mathrm{LDH}$ and substrate can be changed by changing the ratio of metal cationic and the corrosion resistance can be enhanced to prolong the working life of the film. In order to improve the corrosion resistance and other functional effects of $\mathrm{Mg}$ alloy, it is necessary to study the recombination mechanism of LDH interlamination structure, which can maximize the release of inhibitor ions and absorption of corrosion ions to obtain better corrosion resistance of materials. Chemical modification or incorporation of synergistic ions can enhance the compatibility between LDHs and organic polymers, thus increasing the compactness of the composite coating and improving the corrosion resistance of the coating.

With the research on the preparation of $\mathrm{Mg}-\mathrm{Al} \mathrm{LDH}$ coating system on $\mathrm{Mg}$ alloy surface to improve its corrosion resistance, it is particularly important to better grasp how to select the appropriate key parameters and synthesis process. As an LDH film has the main characteristics of positive anticorrosion function, it is necessary to find new regulatory parameters to realize the preparation of multifunctional LDH film withs controllable sizes and specific surface areas, and further improve the protective performance of composite film on $\mathrm{Mg}$ alloys. Therefore, $\mathrm{Mg}-\mathrm{Al} \mathrm{LDH}$ composite films prepared on the surface of $\mathrm{Mg}$ alloy have broad application prospects in Marine corrosion and protection applications.

Author Contributions: Conceptualization, X.Z., X.F. and X.P.; methodology, X.F., M.Z. and X.P.; data curation, C.Y. and D.C.; writing-original draft preparation, X.Z.; writing-review and editing, R.L., Y.Z. and J.R.; All authors have read and agreed to the published version of the manuscript.

Funding: The authors gratefully acknowledge the financial support provided by the National Natural Science Foundation of China (Grant No. 51908092), Projects (No. 2020CDJXZ001 and 2021CDJJMRH005) supported by the Fundamental Research Funds for the Central Universities, the Joint Funds of the National Natural Science Foundation of China-Guangdong (Grant No. U1801254), the project funded by Chongqing Special Postdoctoral Science Foundation (XmT2018043), the Chongqing Research Program of Basic Research and Frontier Technology (cstc2017jcyjBX0080), Natural Science Foundation Project of Chongqing for Post-doctor (cstc2019jcyjbsh0079, cstc2019jcyjbshX0085), Technological projects of Chongqing Municipal Education Commission (KJZDK201800801), the Innovative Research Team of Chongqing (CXTDG201602014) and the Innovative technology of New materials and metallurgy (2019CDXYCL0031). Natural Science Foundation Project of CQ cstc, cstc2017jcyjBX0022.

Institutional Review Board Statement: Not applicable.

Informed Consent Statement: Not applicable.

Data Availability Statement: Not applicable.

Acknowledgments: The authors also thank the Electron Microscopy Center of Chongqing University for materials characterizations.

Conflicts of Interest: The authors declare no conflict of interest. 


\section{References}

1. Li, L.-X.; Xie, Z.-H.; Fernandez, C.; Wu, L.; Cheng, D.; Jiang, X.-H.; Zhong, C.-J. Development of a thiophene derivative modified $\mathrm{LDH}$ coating for Mg alloy corrosion protection. Electrochim. Acta 2020, 330, 135186. [CrossRef]

2. Yan, Y.; Qiu, Y.; Gharbi, O.; Birbilis, N.; Nakashima, P. Characterisation of Li in the surface film of a corrosion resistant Mg-Li(-Al-Y-Zr) alloy. Appl. Surf. Sci. 2019, 494, 1066-1071. [CrossRef]

3. Li, C.-Y.; Gao, L.; Fan, X.-L.; Zeng, R.-C.; Chen, D.-C.; Zhi, K.-Q. In vitro degradation and cytocompatibility of a low temperature in-situ grown self-healing Mg-Al LDH coating on MAO-coated magnesium alloy AZ31. Bioact. Mater. 2020, 5, 364-376. [CrossRef]

4. Xu, D.; Wang, B.; Li, C.; Zu, T.; Han, E. Effect of icosahedral phase on the thermal stability and ageing response of a duplex structured Mg-Li alloy. Mater. Des. 2015, 69, 124-129. [CrossRef]

5. Zhang, Y.; Xu, J.; Ruan, Y.C.; Yu, M.K.; O'Laughlin, M.; Wise, H.; Chen, D.; Tian, L.; Shi, D.; Wang, J.; et al. Implantderived magnesium induces local neuronal production of CGRP to improve bone-fracture healing in rats. Nat. Med. 2016, 22, 1160-1169. [CrossRef] [PubMed]

6. Zhao, Z.W.; Zhao, L.R.; Shi, X.D. Effects of polypropylene carbonate coating on the degradation and biocompatibility of degradable magnesium alloy AZ31. Proc. Est. Acad. Sci. 2019, 68, 13-21. [CrossRef]

7. Chen, J.I.; Fang, L.; Wu, F.; Zeng, X.G.; Hu, J.; Zhang, S.F.; Jiang, B.; Luo, H.J. Comparison of corrosion resistance of MgAl-LDH and ZnAl-LDH films intercalated with organic anions ASP on AZ31 Mg alloys. Trans. Nonferrous Met. Soc. China 2020, 30, 2424-2434. [CrossRef]

8. Subasri, R.; Raju, K.R.C.S.; Reddy, D.S.; Jyothirmayi, A.; Ijeri, V.; Prakash, O.; Gaydos, S.P. Environmentally friendly Zn-Al layered double hydroxide (LDH)-based sol-gel corrosion protection coatings on AA 2024-T3. J. Coat. Technol. Res. 2019, 16, 1447-1463. [CrossRef]

9. Jin, W.; Park, D.-H. Functional layered double hydroxide nanohybrids for biomedical imaging. Nanomaterials 2019, 9, 1404. [CrossRef]

10. Mills, S.J.; Christy, A.; Schmitt, R.T. The creation of neotypes for hydrotalcite. Miner. Mag. 2016, 80, 1023-1029. [CrossRef]

11. Liu, J.-C.; Qi, B.; Song, Y.-F. Engineering polyoxometalate-intercalated layered double hydroxides for catalytic applications. Dalton Trans. 2020, 49, 3934-3941. [CrossRef]

12. Rezvani, Z.; Rad, F.A.; Khodam, F. Synthesis and characterization of Mg-Al-layered double hydroxides intercalated with cubane-1,4-dicarboxylate anions. Dalton Trans. 2015, 44, 988-996. [CrossRef] [PubMed]

13. Iyi, N.; Ebina, Y.; Sasaki, T. Water-swellable MgAl-LDH (layered double hydroxide) hybrids: Synthesis, characterization, and film preparation. Langmuir ACS J. Surf. Colloids 2008, 24, 5591-5598. [CrossRef] [PubMed]

14. Zhang, Y.; Li, Y.; Ren, Y.; Wang, H.; Chen, F. Double-doped LDH films on aluminum alloys for active protection. Mater. Lett. 2017, 192, 33-35. [CrossRef]

15. Mohedano, M.; Serdechnova, M.; Starykevich, M.; Karpushenkov, S.; Bouali, A.; Ferreira, M.; Zheludkevich, M. Active protective PEO coatings on AA2024: Role of voltage on in-situ LDH growth. Mater. Des. 2017, 120, 36-46. [CrossRef]

16. Wang, X.; Jing, C.; Chen, Y.X. Active corrosion protection of super-hydrophobic corrosion inhibitor intercalated Mg-Al layered double hydroxide coating on AZ31 magnesium alloy. J. Alloys Compd. 2021, 8, 291-300. [CrossRef]

17. Cao, Y.; Dong, S.; Zheng, D.; Wang, J.; Zhang, X.; Du, R.; Song, G.-L.; Lin, C. Multifunctional inhibition based on layered double hydroxides to comprehensively control corrosion of carbon steel in concrete. Corros. Sci. 2017, 126, 166-179. [CrossRef]

18. Basu, D.; Das, A.; Stöckelhuber, K.W.; Wagenknecht, U.; Heinrich, G. Advances in layered double hydroxide (LDH)-based elastomer composites. Prog. Polym. Sci. 2014, 39, 594-626. [CrossRef]

19. Li, J.; Lin, K.; Luo, X.; Zhang, H.; Cheng, Y.F.; Li, X.; Liu, Y. Enhanced corrosion protection property of Li-Al layered double hydroxides (LDHs) film modified by 2-guanidinosuccinic acid with excellent self-repairing and self-antibacterial properties. Appl. Surf. Sci. 2019, 480, 384-394. [CrossRef]

20. Zhang, F.; Liu, Z.G.; Zeng, R.C.; Li, S.Q.; Cui, H.Z.; Song, L.; Han, E.H. Corrosion resistance of Mg-Al-LDH coating on magnesi-um alloy AZ31. Surf. Coat. Technol. 2014, 258, 1152-1158. [CrossRef]

21. Wu, W.; Yao, Q.S.; Li, Y.C. Biocorrosion resistance and biocompatibility of Mg-Al layered double hydroxide/poly-L-glutamic acid hybrid coating on magnesium alloy AZ31. Prog. Org. Coat. 2020, 147, 426-441. [CrossRef]

22. Mishra, G.; Dash, B.; Pandey, S. Layered double hydroxides: A brief review from fundamentals to application as evolving biomaterials. Appl. Clay Sci. 2018, 153, 172-186. [CrossRef]

23. Tabish, M.; Yasin, G.; Anjum, M.J.; Malik, M.U.; Zhao, J.; Yang, Q.; Manzoor, S.; Murtaza, H.; Khan, W.Q. Reviewing the current status of layered double hydroxide-based smart nanocontainers for corrosion inhibiting applications. J. Mater. Res. Technol. 2021, 10, 390-421. [CrossRef]

24. Lin, J.; Uan, J. Formation of $\mathrm{Mg}$,Al-hydrotalcite conversion coating on $\mathrm{Mg}$ alloy in aqueous $\mathrm{HCO}^{3-} / \mathrm{CO}^{2-}$ and $\mathrm{corresponding}^{2}$ protection against corrosion by the coating. Corros. Sci. 2009, 51, 1181-1188. [CrossRef]

25. Yang, C.; Yuan, J.; Guo, Y.; Luo, X. In situ nano-assembly of Mg/Al LDH embedded on phosphorylated cellulose microspheres for tetracycline hydrochloride removal. Cellulose 2020, 28, 301-316. [CrossRef]

26. Hu, T.; Ouyang, Y.; Xie, Z.H.; Wu, L. One-pot scalable in situ growth of highly corrosion-resistant MgAl-LDH/MBT composite coating on magnesium alloy under mild conditions. J. Mater. Sci. Technol. 2021, 92, 225-235. [CrossRef]

27. Anjum, M.J.; Zhao, J.; Asl, V.Z.; Yasin, G.; Wang, W.; Wei, S.; Zhao, Z.; Khan, W.Q. In-situ intercalation of 8-hydroxyquinoline in $\mathrm{Mg}-\mathrm{Al} \mathrm{LDH}$ coating to improve the corrosion resistance of AZ31. Corros. Sci. 2019, 157, 1-10. [CrossRef] 
28. Chen, J.; Song, Y.; Shan, D.; Han, E.-H. Influence of alloying elements and microstructure on the formation of hydrotalcite film on Mg alloys. Corros. Sci. 2015, 93, 90-99. [CrossRef]

29. Richetta, M.; Medaglia, P.; Mattoccia, A.; Varone, A.; Pizzoferrato, R. Layered double hydroxides: Tailoring interlamellar nanospace for a vast field of applications. J. Mater. Sci. Eng. 2017, 6, 2122-2169.

30. Yao, Q.S.; Li, Z.C.; Qiu, Z.M. Corrosion resistance of $\mathrm{Mg}(\mathrm{OH}) 2$ /Mg-Al-layered double hydroxide coatings on magnesium alloy AZ31: Influence of hydrolysis degree of silane. Rare Met. 2019, 38, 76-84. [CrossRef]

31. Li, C.-F.; Wang, M.-J.; Ho, W.-H.; Li, H.-N.; Yen, S.-K. Effects of electrolytic MgO coating parameters on corrosion resistance of AZ91D magnesium alloy. J. Electrochem. Soc. 2011, 158, C11-C16. [CrossRef]

32. Liao, L.; Zhao, N.; Xia, Z. Hydrothermal synthesis of $\mathrm{Mg}-\mathrm{Al}$ layered double hydroxides $(\mathrm{LDHs})$ from natural brucite and $\mathrm{Al}(\mathrm{OH})_{3}$. Mater. Res. Bull. 2012, 47, 3897-3901. [CrossRef]

33. Tang, Y.; Wu, F.; Fang, L.; Guan, T.; Hu, J.; Zhang, S. A comparative study and optimization of corrosion resistance of ZnAl layered double hydroxides films intercalated with different anions on AZ31 Mg alloys. Surf. Coat. Technol. 2019, 358, 594-603. [CrossRef]

34. Bouali, A.; Serdechnova, M.; Blawert, C.; Tedim, J.; Ferreira, M.; Zheludkevich, M. Layered double hydroxides (LDHs) as functional materials for the corrosion protection of aluminum alloys: A review. Appl. Mater. Today 2020, 21, 100857. [CrossRef]

35. Wu, H.; Zhang, L.; Zhang, Y.; Long, S.; Jie, X. Corrosion behavior of Mg-Al LDH film in-situ assembled with graphene on Mg alloy pre-sprayed Al layer. J. Alloy. Compd. 2020, 834, 155107. [CrossRef]

36. Hibino, T.; Ohya, H. Synthesis of crystalline layered double hydroxides: Precipitation by using urea hydrolysis and subsequent hydrothermal reactions in aqueous solutions. Appl. Clay Sci. 2009, 45, 123-132. [CrossRef]

37. Zeng, R.-C.; Liu, Z.-G.; Zhang, F.; Li, S.-Q.; He, Q.-K.; Cui, H.-Z.; Han, E.-H. Corrosion resistance of in-situ Mg-Al hydrotalcite conversion film on AZ31 magnesium alloy by one-step formation. Trans. Nonferrous Met. Soc. China 2015, 25, 1917-1925. [CrossRef]

38. Radulescu, A.; Fetters, L.J.; Richter, D. Polymer-driven wax crystal control using partially crystalline polymeric materials. Adv. Polym. Sci. 2007, 210, 1-100.

39. Ishizaki, T.; Chiba, S.; Watanabe, K.; Suzuki, H. Corrosion resistance of Mg-Al layered double hydroxide container-containing magnesium hydroxide films formed directly on magnesium alloy by chemical-free steam coating. J. Mater. Chem. A 2013, 1, 8968-8977. [CrossRef]

40. Kamiyama, N.; Panomsuwan, G.; Yamamoto, E.; Sudare, T.; Saito, N.; Ishizaki, T. Effect of treatment time in the $\mathrm{Mg}(\mathrm{OH}) 2 / \mathrm{Mg}-\mathrm{Al}$ LDH composite film formed on Mg alloy AZ31 by steam coating on the corrosion resistance. Surf. Coat. Technol. 2016, 286, 172-177. [CrossRef]

41. Yan, L.; Zhou, M.; Pang, X.; Gao, K. One-step in situ synthesis of reduced graphene oxide/Zn-Al layered double hydroxide film for enhanced corrosion protection of magnesium alloys. Langmuir 2019, 35, 6312-6320. [CrossRef] [PubMed]

42. Wu, L.; Ding, X.; Zheng, Z.; Ma, Y.; Atrens, A.; Chen, X.; Xie, Z.; Sun, D.; Pan, F. Fabrication and characterization of an actively protective $\mathrm{Mg}-\mathrm{Al} \mathrm{LDHs} / \mathrm{Al}_{2} \mathrm{O}_{3}$ composite coating on magnesium alloy AZ31. Appl. Surf. Sci. 2019, 487, 558-568. [CrossRef]

43. Liu, Q.; Chen, D.; Kang, Z. One-Step Electrodeposition Process To Fabricate corrosion-resistant superhydrophobic surface on magnesium alloy. ACS Appl. Mater. Interfaces 2015, 7, 1859-1867. [CrossRef] [PubMed]

44. Zhang, J.-M.; Wang, K.; Duan, X.; Zhang, Y.; Cai, H.; Wang, Z.-H. Effect of hydrothermal treatment time on microstructure and corrosion behavior of micro-arc oxidation/layered double hydroxide composite coatings on LA103Z Mg-Li Alloy in 3.5 wt.\% $\mathrm{NaCl}$ solution. J. Mater. Eng. Perform. 2020, 29, 4032-4039. [CrossRef]

45. Zhang, F.; Sun, M.; Xu, S.; Zhao, L.; Zhang, B. Fabrication of oriented layered double hydroxide films by spin coating and their use in corrosion protection. Chem. Eng. J. 2008, 141, 362-367. [CrossRef]

46. Kim, J.-H.; Kang, J.-K.; Lee, S.-C.; Kim, S.-B. Immobilization of layered double hydroxide in poly(vinylidene fluoride)/poly(vinyl alcohol) polymer matrices to synthesize bead-type adsorbents for phosphate removal from natural water. Appl. Clay Sci. 2019, 170, 1-12. [CrossRef]

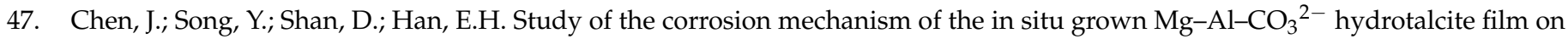
AZ31 alloy. Corros. Sci. 2012, 65, 268-277. [CrossRef]

48. Kaseem, M.; Ramachandraiah, K.; Hossain, S.; Dikici, B. A Review on LDH-smart functionalization of anodic films of Mg alloys. Nanomaterials 2021, 11, 536. [CrossRef]

49. Li, P.; Lv, F.; Xu, Z.; Qi, G.; Zhang, Y. Functions of surfactants in the one-step synthesis of surfactant-intercalated LDHs. J. Mater. Sci. 2013, 48, 5437-5446. [CrossRef]

50. Hang, T.T.X.; Truc, T.A.; Duong, N.T.; Pébère, N.; Olivier, M.-G. Layered double hydroxides as containers of inhibitors in organic coatings for corrosion protection of carbon steel. Prog. Org. Coat. 2012, 74, 343-348. [CrossRef]

51. Chen, J.; Fang, L.; Wu, F.; Xie, J.; Hu, J.; Jiang, B.; Luo, H. Corrosion resistance of a self-healing rose-like MgAl-LDH coating intercalated with aspartic acid on AZ31 Mg alloy. Prog. Org. Coat. 2019, 136, 105234. [CrossRef]

52. Zhang, G.; Wu, L.; Tang, A.; Zhang, S.; Yuan, B.; Zheng, Z.; Pan, F. A Novel approach to fabricate protective layered double hydroxide films on the surface of anodized Mg-Al alloy. Adv. Mater. Interfaces 2017, 4, 4. [CrossRef]

53. Allada, R.K.; Navrotsky, A.; Berbeco, H.T.; Casey, W.H. Thermochemistry and aqueous solubilities of hydrotalcite-like solids. Science 2002, 296, 721-723. [CrossRef]

54. Yu, D.; Wen, S.; Yang, J.; Wang, J.; Chen, Y.; Luo, J.; Wu, Y. RGO modified ZnAl-LDH as epoxy nanostructure filler: A novel synthetic approach to anticorrosive waterborne coating. Surface Coat. Technol. 2017, 326, 207-215. [CrossRef] 
55. Hayatdavoudi, H.; Rahsepar, M. Smart inhibition action of layered double hydroxide nanocontainers in zinc-rich epoxy coating for active corrosion protection of carbon steel substrate. J. Alloy. Compd. 2017, 711, 560-567. [CrossRef]

56. Chen, Y.; Wu, L.; Yao, W.; Zhong, Z.; Chen, Y.; Wu, J.; Pan, F. One-step in situ synthesis of graphene oxide/MgAl-layered double hydroxide coating on a micro-arc oxidation coating for enhanced corrosion protection of magnesium alloys. Surf. Coat. Technol. 2021, 413, 127083. [CrossRef]

57. Zhang, G.; Wu, L.; Tang, A.; Ma, Y.L. Active corrosion protection by a smart coating based on a MgAl-layered double hydroxide on a cerium-modified plasma electrolytic oxidation coating on Mg alloy AZ31. Corros. Sci. 2018, 139, 370-382. [CrossRef]

58. Chen, J.; Song, Y.; Shan, D.; Han, E.-H. Modifications of the hydrotalcite film on AZ31 Mg alloy by phytic acid: The effects on morphology, composition and corrosion resistance. Corros. Sci. 2013, 74, 130-138. [CrossRef]

59. Goh, K.-H.; Lim, T.-T. Influences of co-existing species on the sorption of toxic oxyanions from aqueous solution by nanocrystalline $\mathrm{Mg} / \mathrm{Al}$ layered double hydroxide. J. Hazard. Mater. 2010, 180, 401-408. [CrossRef]

60. Xu, J.; Tan, Q.; Mei, Y. Corrosion protection of steel by Mg-Al layered double hydroxides in simulated concrete pore solution: Effect of SO42-. Corros. Sci. 2020, 163, 163. [CrossRef]

61. Mashtalyar, D.; Nadaraia, K.; Imshinetskiy, I.; Belov, E.; Filonina, V.; Suchkov, S.; Sinebryukhov, S.; Gnedenkov, S. Composite coatings formed on Ti by PEO and fluoropolymer treatment. Appl. Surf. Sci. 2021, 536, 147976. [CrossRef]

62. Wu, Y.; Wu, L.; Zheludkevich, M.L.; Chen, Y.; Serdechnova, M.; Yao, W.; Blawert, C.; Atrens, A.; Pan, F. MgAl-V2O74LDHs/(PEI/MXene)10 composite film for magnesium alloy corrosion protection. J. Mater. Sci. Technol. 2021, 91, 28-39. [CrossRef]

63. Kameda, T.; Uchida, H.; Kumagai, S.; Saito, Y.; Mizushina, K.; Itou, I.; Han, T.; Yoshioka, T. Regeneration of car-bonate-intercalated $\mathrm{Mg}-\mathrm{Al}$ layered double hydroxides $\left(\mathrm{CO}_{3} \cdot \mathrm{Mg}-\mathrm{Al} \mathrm{LDHs}\right)$ by $\mathrm{CO}_{2}$-induced desorption of anions $(\mathrm{X})$ from $\mathrm{X} \cdot \mathrm{Mg}-\mathrm{Al} \mathrm{LDH}(\mathrm{X}=\mathrm{Cl}$, $\mathrm{SO}_{4}$, or $\mathrm{NO}_{3}$ ): A kinetic study. Chem. Eng. Res. Des. 2021, 165, 207-213. [CrossRef]

64. Wu, L.; Wu, J.; Zhang, Z.; Zhang, C.; Zhang, Y.; Tang, A.; Li, L.; Zhang, G.; Zheng, Z.; Atrens, A.; et al. Corrosion resistance of fatty acid and fluoroalkylsilane-modified hydrophobic Mg-Al LDH films on anodized magnesium alloy. Appl. Surf. Sci. 2019, 487, 569-580. [CrossRef]

65. Zhang, X.; Wu, G.; Peng, X.; Li, L.; Feng, H.; Gao, B.; Huo, K.; Chu, P.K. Mitigation of corrosion on magnesium alloy by predesigned surface corrosion. Sci. Rep. 2015, 5, 17399. [CrossRef]

66. Huang, S.; Cen, X.; Zhu, H.; Yang, Z.; Yang, Y.; Tjiu, W.W.; Liu, T. Facile preparation of poly(vinyl alcohol) nanocomposites with pristine layered double hydroxides. Mater. Chem. Phys. 2011, 130, 890-896. [CrossRef]

67. Mallakpour, S.; Dinari, M.; Hatami, M. Novel nanocomposites of poly(vinyl alcohol) and Mg-Al layered double hydroxide intercalated with diacid N-tetrabromophthaloyl-aspartic. J. Therm. Anal. Calorim. 2015, 120, 1293-1302. [CrossRef]

68. Zhang, S.; Wang, T.; Tang, J.; Liu, X.; Shen, Y. Enhanced antitumor effect of poly(L-glutamic acid)-rose bengal conjugate nanoparticle. J. Control. Release 2017, 259, e122-e123. [CrossRef]

69. Laipan, M.; Xiang, L.; Yu, J.; Martin, B.R.; Zhu, R.; Zhu, J.; He, H.; Clearfield, A.; Sun, L. Layered intercalation compounds: Mechanisms, new methodologies, and advanced applications. Prog. Mater. Sci. 2020, 109, 100631. [CrossRef]

70. Kaseem, M.; Ko, Y.G. A novel hybrid composite composed of albumin, $\mathrm{WO}_{3}$, and $\mathrm{LDH}$ film for smart corrosion protection of $\mathrm{Mg}$ alloy. Compos. Part. B Eng. 2021, 204, 108490. [CrossRef]

71. Peng, F.; Wang, D.; Zhang, D.; Yan, B.; Cao, H.; Qiao, Y.; Liu, X. PEO/Mg-Zn-Al LDH Composite Coating on Mg Alloy as a $\mathrm{Zn} / \mathrm{Mg}$ Ion-Release Platform with Multifunctions: Enhanced Corrosion Resistance, Osteogenic, and Antibacterial Activities. ACS Biomater. Sci. Eng. 2018, 4, 4112-4121. [CrossRef] [PubMed] 